\title{
Experiência Clínica com o Uso de Sedativos em Terapia Intensiva. Estudo Retrospectivo *
}

\section{Clinical Experience with Sedatives in the Intensive Care Unit. A Retrospective Study}

Geraldo Rolim Rodrigues Júnior ${ }^{1}$, José Luiz Gomes do Amaral, TSA ${ }^{2}$

\section{RESUMO}

Rodrigues Jr GR, Amaral JLG - Experiência Clínica com o Uso de Sedativos em Terapia Intensiva. Estudo Retrospectivo

Justificativa e Objetivos - Dentre as indicações mais freqüentes de sedação em pacientes internados em Unidades de Terapia Intensiva (UTI) estão a instituição e a manutenção de ventilação artificial, a ansiedade e procedimentos desconfortáveis ou dolorosos. O objetivo deste estudo retrospectivo foi verificar as indicações e as técnicas mais comuns de sedação em pacientes graves internados na Unidade de Terapia Intensiva Cirúrgica da Escola Paulista de Medicina (EPM/UNIFESP) durante um período de 11 meses.

Método - Após terem sido excluídos os pacientes que permaneceram na UTI menos de 24 horas ou estavam sem exames indispensáveis para o cálculo do índice de gravidade (APACHE II), a amostra ficou reduzida a 307 pacientes. Foram analisadas as técnicas mais utilizadas, as indicações de sedação e a associação de bloqueadores neuromusculares.

Resultados - A sedação foi administrada em $37,4 \%$ dos pacientes. Entre as indicações de sedação estão os distúrbios de natureza psiquiátrica, como delírio, agitação, medo e ansiedade. Estas corresponderam a $25,77 \%$ de todas as indicações. A maioria dos pacientes ventilados artificialmente também necessita de sedativos. Instalação e manutenção de ventilação mecânica corresponderam à maioria das indicações, em torno de $57,73 \%$ dentre os pacientes sedados. Procedimentos como intubação traqueal e broncoscopia tiveram $11,34 \%$ das indicações e controle do metabolismo (coma barbitúrico e tétano), 5,15\%. As técnicas mais comumente utilizadas incluíram opióides isolados ou associados a benzodiazepínicos. Neste estudo, o fentanil foi utilizado em 58\% das técnicas, isoladamente, e em $21,64 \%$ associado ao midazolam. Haloperidol, diazepam, propofol e tiopental somaram $19,5 \%$. Bloqueadores neuromusculares foram utilizados em $22,7 \%$ dos casos em pacientes ventilados artificialmente.

Conclusões - A sedação é recurso terapêutico freqüente em Terapia Intensiva, comumente utilizada para facilitar a ventilação artificial e tratar os problemas de natureza

\footnotetext{
* Recebido do (Received from) Departamento de Anestesiologia da Faculdade de Medicina de Botucatu (FMB - UNESP), Botucatu, SP

1. Professor Assistente Doutor do Departamento de Anestesiologia da FMB - UNESP

2. Professor Titular da Disciplina de Anestesiologia, Dor e Terapia Intensiva Cirúrgica da EPM/UNIFESP
}

Apresentado (Submitted) em 03 de janeiro de 2002

Aceito (Accepted) para publicação em 29 de abril de 2002

Correspondência para (Mail to):

Dr. Geraldo Rolim Rodrigues Júnior

Dept ${ }^{\circ}$ de Anestesiologia da FMB - UNESP

Distrito de Rubião Júnior

18618-970 Botucatu, SP

(C) Sociedade Brasileira de Anestesiologia, 2002 psiquiátrica. Fentanil, isoladamente ou em associação com midazolam, foi o agente mais utilizado.

UNITERMOS: SEDAÇÃO; TERAPIA INTENSIVA

\section{SUMMARY}

Rodrigues Jr GR, Amaral JLG - Clinical Experience with Sedatives in the Intensive Care Unit. A Retrospective Study.

Background and Objectives - Among the most frequent indications for Intensive Care Unit patients sedation, one may mention artificial ventilation installation and maintenance, anxiety and uncomfortable or painful procedures. This retrospective study aimed at evaluating most common sedation indications and techniques for severe patients admitted to the Surgical Intensive Care Unit, Escola Paulista de Medicina (EPM/UNIFESP) during an 11-month period.

Methods - After excluding patients remaining in the ICU for less than 24 hours and those without the necessary evaluation to determine their severity index (APACHE II), the sample was reduced to 307 patients. Most common techniques, sedation indications and neuromuscular blockers association were evaluated.

Results - Sedation was administered to $37.4 \%$ of patients. Psychiatric disorders, such as delirium, agitation, fear and anxiety, were some indications for sedation and corresponded to $25.77 \%$ of all indications. Most ventilated patients also needed sedative agents and mechanical ventilation installation and maintenance represented most indications, or approximately $57.73 \%$ of all sedated patients. Procedures, such as tracheal intubation and bronchoscopy, represented $11.34 \%$ of all indications and metabolic control (barbiturate coma and tetanus) represented $5.15 \%$ of the cases. Most common sedative techniques included opioids alone or associated to benzodiazepines. In this study, fentanyl alone was used in 58\% of the cases, and fentanyl plus midazolam in $21.64 \%$ of patients. Haloperidol, diazepam, propofol and thiopental added up $19.5 \%$. Neuromuscular blockers were used in $22.7 \%$ of mechanically in ventilated patients.

Conclusions - Sedation is a common therapeutic resource for intensive care and is widely used to help mechanical ventilation and to treat psychiatric disorders. Fentanyl, alone or in association with midazolam, was the most widely used agent.

KEY WORDS: INTENSIVE CARE; SEDATION

\section{INTRODUÇÃO}

A rotina das unidades de terapia intensiva é caracterizada Apor ritmo ininterrupto e atividade constante, luzes, ruídos e uso de aparelhos estranhos, provocando medo e ansiedade. Outra causa de ansiedade é a relativa imobilidade que alguns sistemas sensíveis de monitorização exigem. Isso requer paciência e colaboração além dos limites impostos pelas enfermidades graves. 
É pouco provável que uma pessoa possa tolerar tal ambiente sem que seja instituído algum tratamento para a ansiedade, além do indispensável alívio da dor.

Ansiedade e medo, responsáveis pelo sofrimento psíquico a que são submetidos os egressos dessas unidades, são dificilmente avaliáveis e preocupam em demasia pesquisadores e estudiosos da área ${ }^{1,2}$, principalmente por serem prováveis desencadeadores da síndrome descrita, genericamente, como "psicose de UTI", que apresenta incidência entre $14 \%$ e $72 \%{ }^{3}$. Esta síndrome pode cursar com agitação leve e até com intensa agressividade e violência, exigindo contenção física imediata ou sedação. Nos acometidos de doença coronariana ou insuficiência respiratória aguda, a agitação pode afetar desfavoravelmente a evolução clínica. Torna-se óbvia, nesse caso, a relevância da sedação.

Vários relatos descrevem poucas queixas em relação à internação nessas unidades ${ }^{4,5}$. Outros, contudo, afirmam que nenhum egresso dessas unidades está isento de algum distúrbio psicológico ${ }^{6}$. Seja ou não considerada uma entidade nosológica, essa "psicose" pode ser prevenida pela eliminação da tríade ansiedade, dor e insônia ${ }^{7-9}$. Maior relevância recai, ainda, em humanização dos cuidados intensivos que, auxiliando na capacidade adaptativa desses enfermos, pode amenizar sua experiência nessas unidades ${ }^{10}$.

Apesar dos esforços de humanização das unidades, os objetivos primários do tratamento intensivo tornaram-se a aprendizagem e utilização de sofisticados recursos de monitorização e terapêutica, esquecendo que, na outra extremidade dos tubos, cabos e drenos e atrás de alarmes, encontra-se um ser humano fragilizado pela doença subjacente.

Portanto, a sedação em terapia intensiva deve ser encarada como um aspecto terapêutico importante do tratamento. $\mathrm{O}$ conhecimento de sua correta utilização adquire maior relevo sabendo-se que cerca de $30 \%$ a $50 \%$ dos pacientes internados nestas unidades recebem alguma forma de sedação ${ }^{11,12}$. Mesmo verificando utilização crescente, a sedação não tem, até recentemente, despertado interesse científico entre boa parte dos especialistas da área, em relação a outros aspectos do tratamento e, não raro, é baseada em aspectos subjetivos. Alguns autores lembram que drogas sedativas são prescritas com maior freqüência para compensar inquietações da equipe médica ou prover condições convenientes para a prática de enfermagem, do que em resposta às necessidades dos pacientes ${ }^{13}$.

Entre as indicações mais freqüentes de sedação estão a instituição e manutenção de ventilação artificial, procedimentos desconfortáveis ou dolorosos, como a intubação traqueal e diversas intervenções. No tétano e no trauma craniencefálico, a sedação profunda pode ser parte integrante do tratamento.

O objetivo deste estudo foi verificar as indicações e as técnicas de sedação mais comuns utilizadas em pacientes graves internados na Unidade de Terapia Intensiva Cirúrgica da Escola Paulista de Medicina (EPM/UNIFESP). Verificou-se, também, a associação de bloqueadores neuromusculares às técnicas de sedação.

\section{MÉTODO}

Após aprovação pela Comissão de Ética desta Instituição, foram incluídos neste estudo, pacientes internados na Unidade de Terapia Intensiva Cirúrgica (UTI) da Disciplina de Anestesiologia, Dor e Terapia Intensiva Cirúrgica do Departamento de Cirurgia da EPM/UNIFESP admitidos em período de 11 meses durante o ano de 1994.

Para avaliação da freqüência de utilização de sedação, foram analisados, retrospectivamente, os prontuários dos 492 pacientes internados no período do estudo e identificados aqueles que receberam sedativos.

Foram então excluídos da casuística inicial todos os pacientes que tivessem permanecido menos de vinte e quatro horas na unidade e os que não tivessem documentados os exames complementares indispensáveis para o cálculo do índice de gravidade e prognóstico APACHE II ${ }^{14}$.

Foram selecionados 307 pacientes divididos em dois grupos: grupo não-sedado (GNS) constituído de pacientes que não receberam nenhum tipo de sedativo e grupo sedado (GS), com aqueles sedados em sua internação. O primeiro foi constituído de 192 pacientes, enquanto o segundo, de 115.

Os dois grupos foram comparados em relação a sexo, idade e gravidade inicial conforme o índice APACHE II ${ }^{14}$.

Para análise estatística dos resultados foram utilizados testes não-paramétricos, levando-se em conta a natureza das variáveis estudadas. Foram aplicados os seguintes testes:

1. Teste de Mann-Whytney ${ }^{15}$ para grupos independentes, comparando os grupos sedado e não-sedado em relação aos valores do APACHE II, dias de internação e idade em anos. Este teste foi feito com aproximação à curva normal (Estatística z).

2. Teste do Qui-quadrado ${ }^{15}$ para tabelas de associação, comparando os grupos sedado e não-sedado em relação às características estudadas. Quando foram observadas as restrições de Cochran, aplicou-se o teste Exato de Fisher ${ }^{15}$.

Em todos os testes fixou-se em 0,05 ou $5 \%$ (alfa < ou $=0,05)$ o nível de rejeição da hipótese de nulidade, assinalando-se com um asterisco os valores significantes.

\section{RESULTADOS}

De 185 pacientes excluídos, seis foram submetidos à sedação, enquanto que 179 restantes o não foram. Daqueles não sedados e excluídos, 30 o foram por serem apenas doadores de órgãos para transplante ou por terem permanecido na UTI menos que doze horas. Dos outros 149 não submetidos à sedação, 130 permaneceram menos de vinte e quatro horas internados, não permitindo o cálculo do APACHE II, e 19 pacientes não puderam ser submetidos à avaliação por ausência de exames indispensáveis.

Revista Brasileira de Anestesiologia Vol. 52, № 6, Novembro - Dezembro, 2002 
Restaram 307 pacientes, 182 pacientes pertenciam ao sexo masculino e 125 ao feminino. Aidade média foi de 52,5 anos, com variação de 12 a 88 anos.

A sedação foi encontrada em $24 \%$ da totalidade dos pacientes internados e $37 \%$ quando considerados os que permaneceram mais que 24 horas Entre as indicações de sedação mais comuns estão os distúrbios de natureza psiquiátrica (delírio, agitação, medo e ansiedade) e a adaptação à ventilação mecânica (Figura 1). Nos pacientes portadores de distúrbios de natureza psiquiátrica foram observados alguns componentes de desorganização psicológica, como desilusão, pânico, sensação de abandono e até mesmo psicose.

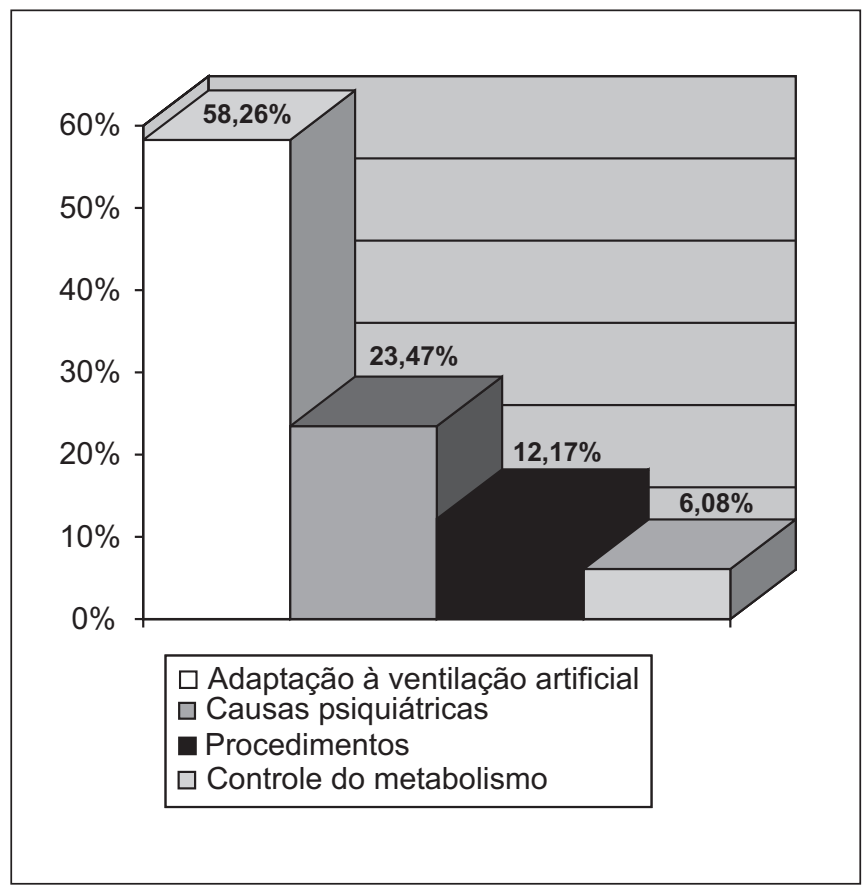

Figura 1 - Indicações mais Comuns para o Uso de Sedativos em Pacientes Graves

O fentanil foi o fármaco mais utilizado isoladamente ou em associação com midazolam. Haloperidol, diazepam, propofol e tiopental foram incluídos em "outros" (Figura 2). A porcentagem de bloqueadores neuromusculares administrados para complementar a sedação em pacientes ventilados artificialmente e os mais utilizados estão apresentados na figura 3 . Arelação entre as indicações mais comuns e o tipo de técnica escolhida estão exemplificados na figura 4.

\section{DISCUSSÃo}

Sedação e analgesia são aspectos essenciais na condução do paciente em Unidade de Tratamento Intensivo. $O$ ato ou efeito de sedar, do latim sedatum, significa moderar a ação excessiva, acalmar, serenar, aquele que está excitado. Sedação pode ser também definida como situação na qual foi removido ou atenuado estado preexistente de ansiedade, por meios farmacológicos, ou ainda, quando não se desen- volvem sinais de ansiedade em circunstâncias nas quais se esperava que ocorressem ${ }^{10}$.

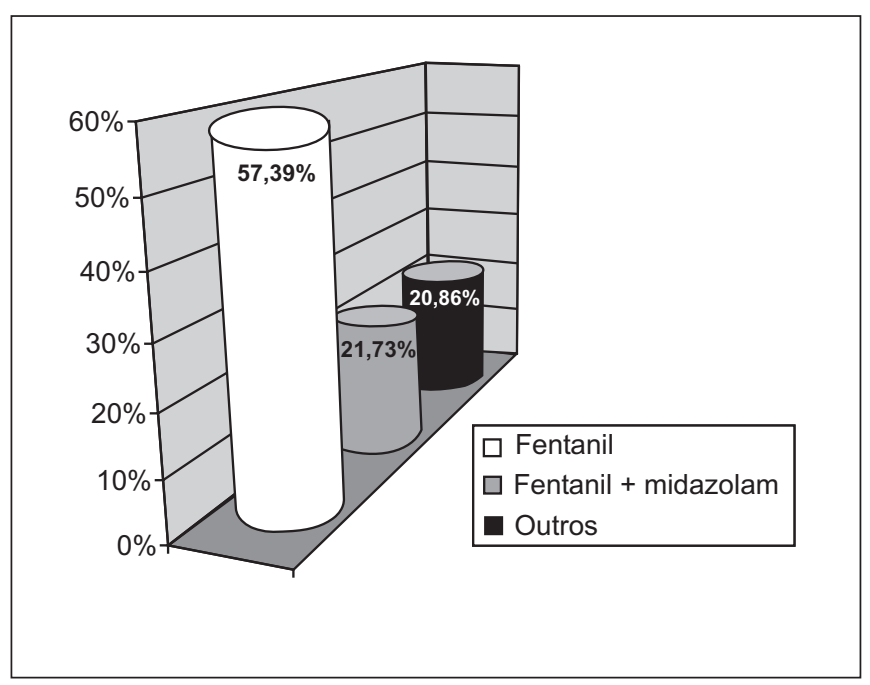

Figura 2 - Medicações mais Utilizadas para Sedação dos Pacientes Internados

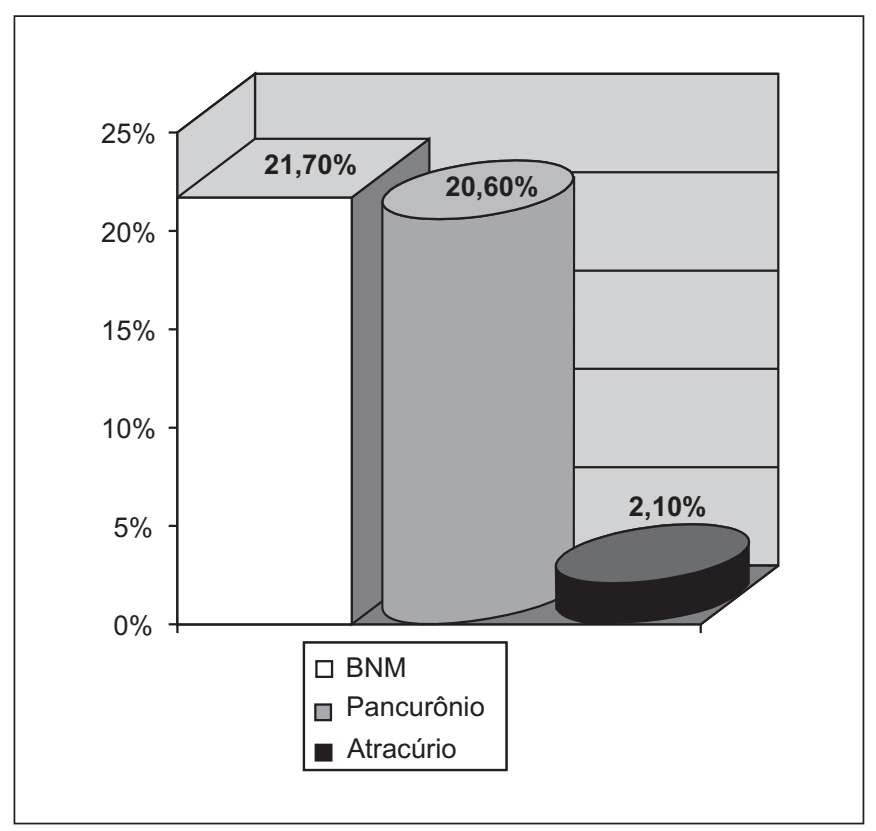

Figura 3 - Porcentagem de Pacientes Ventilados Artificialmente que Receberam Bloqueadores Neuromusculares (BNM) e os mais Usados nesses Casos

Asedação visa trazer ao paciente grave, conforto físico e psicológico ${ }^{16}$. Ela requer três elementos básicos: compaixão, comunicação e competência no uso de técnicas e agentes sedativos $^{10}$

Apesar da dificuldade em quantificar os benefícios da sedação e da escassez de informações acerca de sua utilização em UTI, ela encontra larga aplicação nesta área ${ }^{16}$. Segundo Aitkenhead ${ }^{17}$, a maioria dos pacientes admitidos em UTI necessita de analgesia ou sedação ou ambas, durante a internação. 


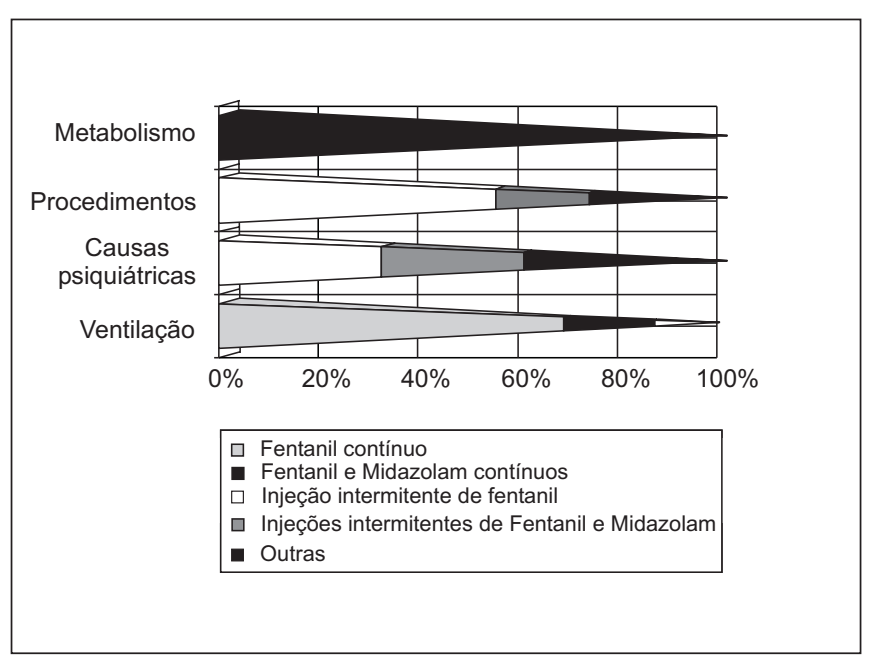

Figura 4 - Técnicas e Agentes Sedativos Usados e Relacionados com as Indicações mais Comuns

Pesquisadores verificaram que, em diversas instituições, $40 \%$ dos pacientes sob cuidados intensivos receberam drogas sedativas ${ }^{12}$. Esses resultados confirmam outras pesquisas que mostram elevada utilização de drogas sedativas, empregadas em $30 \%$ a $50 \%$ dos pacientes graves ${ }^{11,18}$.

Paralelamente, neste estudo, verificou-se que, se considerados apenas os pacientes internados por período superior a 24 horas, o uso de sedativos foi de $37,4 \%$, proporção esta que cai para $24,6 \%$ quando considerados todos os enfermos do período, inclusive os 182 excluídos por permanecerem internados em período inferior a 24 horas, seja por óbito, por serem doadores de órgãos ou por não apresentarem todos os requisitos para o cálculo do índice de gravidade.

O tratamento intensivo necessita de paciência e colaboração. Alguns desses doentes apresentam alteração do sensório como conseqüência direta de disfunção orgânica ${ }^{19}$. Inclusive, nesses casos, o uso de sedativos pode ser benéfi$\mathrm{co}$, reduzindo o impacto psicológico e facilitando o tratamento dos distúrbios somáticos ${ }^{1}$.

As complicações psiquiátricas mais comumente observadas são delírio e agitação. No delírio incluem-se alterações da sensopercepção e do sono, desorientação e agitação psicomotora ${ }^{20}$. O apoio psicológico reduz a incidência destes fenômenos em $14 \%$ a $33 \%{ }^{10}$. Estes distúrbios raramente ocorrem associados à psicose verdadeira. Aexpressão "psicose de UTI" é descrição simplista e inespecífica dos distúrbios de comportamento resultantes da perda de contato com a realidade ${ }^{1}$.

Medo e ansiedade constituem relevante estresse psíquico. Eles são influenciados por fatores genéticos e experiências prévias (próprias ou de conhecidos). A ansiedade pode resultar em desorganização psicológica, expressa por desilusão, pânico, sensação de abandono e até mesmo psicose ${ }^{13}$. A presença de alguns desses componentes foi observada nesta pesquisa nos doentes acometidos de agitação ou delírios, englobados, aqui, genericamente, como distúrbios de natureza psiquiátrica. Essas causas, geralmente, estavam ligadas à agitação psicomotora e corresponderam a 25,77\% das indicações de sedação.

Uma equipe amigável e um ambiente acolhedor (controles de ruído, luminosidade e temperatura) evitam esta seqüência devastadora. As visitas de familiares e amigos reforçam sobremaneira o apoio recebido da equipe médica e paramédica ${ }^{10}$.

Problemas respiratórios são comuns em UTI. Enfermidades pulmonares, ou não, podem levar à necessidade de suporte ventilatório prolongado ou temporário. Nestes pacientes, a presença do tubo traqueal, o ruído monótono do ventilador, além do medo e da ansiedade, impedem o sincronismo entre ventilação espontânea e mecânica ${ }^{3}$. Um medicamento ansiolítico e hipnótico pode ser útil para maior tolerância.

Atolerância ao tubo traqueal é variável, sendo a sonda nasotraqueal mais aceita. A traqueostomia prescinde de sedação. A aspiração traqueal, porém, já foi descrita como sufocante, chegando ao limite da tolerabilidade. O ventilador mecânico, no início do tratamento, chega a ser uma experiência aterrorizante ${ }^{10}$. Neste momento, a associação de opióides será útil por reduzir a resistência ao ventilador artificial e promover analgesia.

A seleção apropriada e o ajuste do método de ventilação mecânica eliminam a necessidade de bloqueadores neuromusculares e sedação excessiva em muitos pacientes adultos. Apesar disto, a adaptação do paciente à ventilação mecânica constitui a principal indicação de sedação, como foi demonstrada no presente estudo, no qual contabilizaram-se $57,73 \%$ de todas as circunstâncias para as quais foram administrados sedativos. Cerca de $90 \%$ dos que se submetem aos ventiladores artificiais recebem tais fármacos, podendo chegar a $100 \%$ dos casos.

Diversos procedimentos são realizados sob anestesia local, sem necessidade de sedação. Intervenções extensas e agressivas, entretanto, necessitam de sedação ou mesmo anestesia geral ${ }^{2}$. A intubação traqueal é exemplo de situação que requer, por breve lapso de tempo, depressão da consciência ${ }^{13}$. Por isso, procedimentos desconfortáveis ou dolorosos corresponderam a $11,34 \%$ de todas as indicações de sedação.

Uma vez que a perda dos padrões fisiológicos do sono tem profundas implicações metabólicas nos pacientes hospitalizados, o tratamento da insônia é motivo apropriado para o emprego de sedativos, porém não é verificado em mais do que $5,15 \%$ dos casos de sedação.

A sedação ideal deve atender ao conforto do enfermo sem determinar significante depressão da consciência. Limites assim estreitos tornam a sedação, em terapia intensiva, um exercício da arte médica, na qual intervenções farmacológicas representam apenas um fator, ao lado do controle ambiental e da sensibilidade da equipe ${ }^{10,13}$.

Narcóticos, associados ou não a benzodiazepínicos, aumentam a tolerância ao tubo traqueal, atenuam o reflexo da tosse e inibem os centros respiratórios. É assim possível adaptar o paciente à atividade automática do ventilador, sem contudo abolir por completo a consciência e a cooperação. 
Os morfinomiméticos são os agentes mais freqüentemente administrados para analgesia ou sedação (37\% isoladamente e $60 \%$ associados a benzodiazepínicos) ${ }^{2,10,21}$.

Fentanil foi o agente analgésico mais administrado no presente estudo (58\% das técnicas). Ele foi aplicado isoladamente em injeção contínua, em 39,17\% dos casos, e em injeções intermitentes isoladas, em $19,58 \%$ dos casos. Em recente censo nacional realizado pela Associação de Medicina Intensiva Brasileira (AMIB) ${ }^{22}$ também foi constatada a preferência por fentanil pela maioria dos especialistas brasileiros. Contudo, pelas recomendações do comitê formado pelas Sociedade e Colégio Americano de Medicina Intensiva $(\mathrm{SCCM} \text { e ACCCM })^{23}$, a morfina é a primeira escolha, principalmente devido ao baixo custo. O mesmo comitê definiu a utilização do fentanil para situações de liberação histamínica e instabilidade hemodinâmica. Nas reuniões promovidas pela AMIB em 1997 e 1999, o comitê formado recomendou morfina e fentanil, igualmente, como primeira opção (intervenções ou fármacos recomendados a partir das evidências científicas disponíveis e suficiente experiência clínica no Brasil) ${ }^{24,25}$.

Os benzodiazepínicos estão entre as drogas mais comumente prescritas. Diazepam ainda é bastante usado para sedação em terapia intensiva ${ }^{10,11,20}$. Midazolam também é amiúde utilizado isoladamente ${ }^{26}$ ou em associação com narcóti$\cos ^{26,28}$.

Na casuística aqui analisada, o diazepam foi administrado, principalmente, no tratamento do tétano (2 pacientes em 307). A escolha do agente hipnótico recai, geralmente, sobre o midazolam, principalmente pela hidrossolubilidade, curta meia-vida de eliminação e custo relativamente baixo. O propofol demonstra uma série de propriedades adequadas para sedação em UTI, como meia-vida de ação extremamente curta, mesmo em infusões prolongadas, e pode ser melhor opção que o midazolam em uma série de situações ${ }^{10,17,18}$. Sua grande limitação encontra-se, ainda, no custo.

Haloperidol foi empregado na agitação psicomotora e é preferido no tratamento do delírio, segundo consenso das SCCM e ACCCM ${ }^{23}$; tiobarbiturato de sódio ("coma barbitúrico"), no controle da hipertensão intracraniana e do sofrimento neurológico ${ }^{2,10,17}$; propofol em injeção contínua para sedação de pacientes respirando artificialmente, sendo sua baixa utilização, nesta pesquisa, devido às poucas unidades adquiridas pelo nosocômio em questão.

Diazepam, haloperidol, tiopental e propofol somados corresponderam a $19,5 \%$ de todas as técnicas empregadas na sedação dos pacientes desta pesquisa.

Os bloqueadores neuromusculares complementam as técnicas de sedação de pacientes ventilados artificialmente ${ }^{29}$. Esta combinação (particularmente com o pancurônio) já foi utilizada em até $91 \%$ dos casos ${ }^{30}$. Outros autores verificaram o uso de pancurônio em apenas $16 \%$ e $15 \%$ das unidades estudadas ${ }^{11,22}$. Observou-se, na presente investigação, o uso de pancurônio em $20,6 \%$ dos pacientes sedados, sendo administrado somente nos casos refratários aos sedati- vos ou com dificuldade de manter parâmetros ventilatórios adequados.

Atracúrio é outro bloqueador neuromuscular útil, em menor escala ${ }^{30,31}$. Esse fato é ressaltado pelo seu preço elevado e pela necessidade de uso contínuo. Contudo, é de escolha nos casos de insuficiência renal, como ocorreu em todos os casos verificados nesta investigação.

A sedação é um recurso terapêutico freqüente em UTI, comumente indicada para adaptação à ventilação artificial e tratamento da agitação psicomotora. O fentanil, isoladamente ou em associação com o midazolam, foi o agente mais utilizado.

\section{Clinical Experience with Sedatives in the Intensive Care Unit. A Retrospective Study}

Geraldo Rolim Rodrigues Júnior, M.D., José Luiz Gomes do Amaral, TSA, M.D.

\section{INTRODUCTION}

The routine of Intensive Care Units is characterized by a hectic pace and continuous light, noise and the use of unknown devices which cause fear and anxiety. Another reason for anxiety is the relative immobility required by some sensitive monitoring equipment. These ask for patience and cooperation beyond the limits imposed by severe diseases.

It is less likely that a person will stand such environment without any anxiolytic treatment and the indispensable pain relief.

Anxiety and fear, responsible for the psychic suffering inflicted to patients just leaving such units are difficult to evaluate and are of great concern for researchers in this area ${ }^{1,2}$, especially for being potential triggering factors for the syndrome popularly described as "ICU psychosis", with an incidence of $14 \%$ to $72 \%{ }^{3}$. This syndrome may be followed by mild agitation or even by intense aggressiveness and violence, requiring immediate physical contention or sedation. In coronary or acute respiratory failure patients, agitation may negatively affect clinical evolution, thus making obvious the relevance of sedation.

Some studies report few complains about being in the ICU ${ }^{4,5}$. Others, however, state that no patient leaving these units is free from some psychological disorder ${ }^{6}$. Regardless of being or not considered nosologic, such "psychosis" may be prevented by removing the triad anxiety, pain and insomnia ${ }^{7,9}$. Even more relevant it is to humanize intensive care which, while helping those patients in their adaptative ability, may minimize their experience with such units ${ }^{10}$.

In spite of humanizing efforts, primary intensive care objectives became the learning and using of sophisticated monitoring and therapeutic resources, forgetting that, at the other 
end of catheters, cables and drains and behind alarms, there is a human being weakened by the underlying disease. So, intensive care sedation should be seen as an important therapeutic tool. Its correct utilization is more relevant when it is known that approximately $30 \%$ to $50 \%$ of ICU patients receive some type of sedation ${ }^{11,12}$. Even being increasingly used, until recently sedation was not the object of scientific interest on the part of many specialists, as compared to other aspects of the treatment and, not uncommonly, was based on subjective aspects. Some authors remind that sedative drugs are more frequently prescribed to balance medical staff concerns or to provide convenient conditions for the nursing team, than to respond to patients' needs ${ }^{13}$.

Among the most common indications for sedation there are mechanical ventilation installation and maintenance, uncomfortable or painful procedures, such as tracheal intubation and several interventions. For tetanus and brain trauma, deep sedation may be an integral part of the treatment.

This study aimed at evaluating most common sedation indications and techniques for severe patients admitted to the Surgical Intensive Care Unit, Escola Paulista de Medicina (EPM/UNIFESP). The association of neuromuscular blockers to sedation techniques was also evaluated.

\section{METHODS}

After the Hospital's Ethical Committee approval, participated in this study patients admitted to the Surgical Intensive Care Unit (ICU) of the Anesthesiology, Pain and Surgical Intensive Care discipline, Surgery Department, EPM/UNIFESP, during an 11-month period in the year 1994 .

To evaluate sedation frequency, the records of 492 patients were retrospectively studied to identify those receiving sedative drugs.

Exclusion criteria were patients remaining in the ICU for less than 24 hours and those without documented exams for severity index calculation and APACHE II prognosis ${ }^{14}$. The sample was reduced to 307 patients who were divided in two groups: non-sedated group (NSG), with patients not receiving any type of sedatives $(n=192)$; and sedated group (SG), with patients who were sedated while admitted $(n=115)$.

Both groups were compared as to gender, age and initial severity according to APACHE II index ${ }^{14}$.

Non-parametric tests were used for statistical analysis of results, taking into account the nature of studied variables. The following tests were applied:

1. Mann-Whytney test ${ }^{15}$ for independent groups, comparing sedated and non-sedated groups in terms of APACHE II values, ICU stay and age in years. This test was performed with approximation to the normal curve (Z statistics).
2. Chi-square test ${ }^{15}$ for association tables, comparing sedated and non-sedated groups in terms of studied characteristics. Fisher Exact test was applied in the presence of Cochran's restrictions ${ }^{15}$.

Null hypothesis rejection level was established as 0.05 or $5 \%$ (alpha $<$ or $=0.05$ ) and significant values were highlighted with a $\operatorname{star}\left({ }^{*}\right)$.

\section{RESULTS}

From the 185 excluded patients, six were submitted to sedation, while the remaining 179 were not. From those non-sedated and excluded, 30 were excluded for being just transplant organ donors or for having remained in the ICU for less than 12 hours. From the remaining 149 non-sedated patients, 130 have remained in the ICU for less than 24 hours not allowing for APACHE II calculation, and 19 patients could not be submitted to evaluation due to the lack of mandatory exams.

The sample remained with 307 patients: 182 male and $125 \mathrm{fe}-$ male. Mean age was 52.5 years, varying from 12 to 88 years.

Sedation was administered to $24 \%$ of all admitted patients and to $37 \%$ of those admitted for more than 24 hours. Psychiatric disorders (delirium, agitation, fear and anxiety) and mechanical ventilation were among the most common indications for sedation (Figure 1). Psychiatric disorder patients presented some psychological disorganization components, such as delusion, panic, abandonment and even psychosis.

Fentanyl was the most widely used drug, both isolated or in association with midazolam. Haloperidol, diazepam, propofol and thiopental were included as "Others" (Figure 2). Figure 3 shows the percentage of most common NMBs administered to mechanically ventilated patients to complement sedation.

Figure 4 shows most common indications and the techniques of choice.

\section{DIsCUSSION}

Sedation and analgesia are essential in managing Intensive Care Unit patients. The act or effect of sedating, from the Latin sedatum, means to moderate excessive action, to relax, and calm an excited individual. Sedation may also be defined as a situation where a preexisting anxiety is removed or minimized by pharmacological means, or even, when anxiety is not developed in a situation where it was to be expected ${ }^{10}$. Sedation aims at bringing the patient physical and psychological comfort ${ }^{16}$. It requires three basic elements: compassion, communication and competence in the use of sedative agents and techniques ${ }^{10}$.

In spite of the difficulty in quantifying the benefits of sedation and the lack of information about its use in Intensive Care Units, it is widely used in this area ${ }^{16}$. According to Aitkenhead 17 , most patients admitted to the ICU need analgesia or sedation, or both, during their stay. 


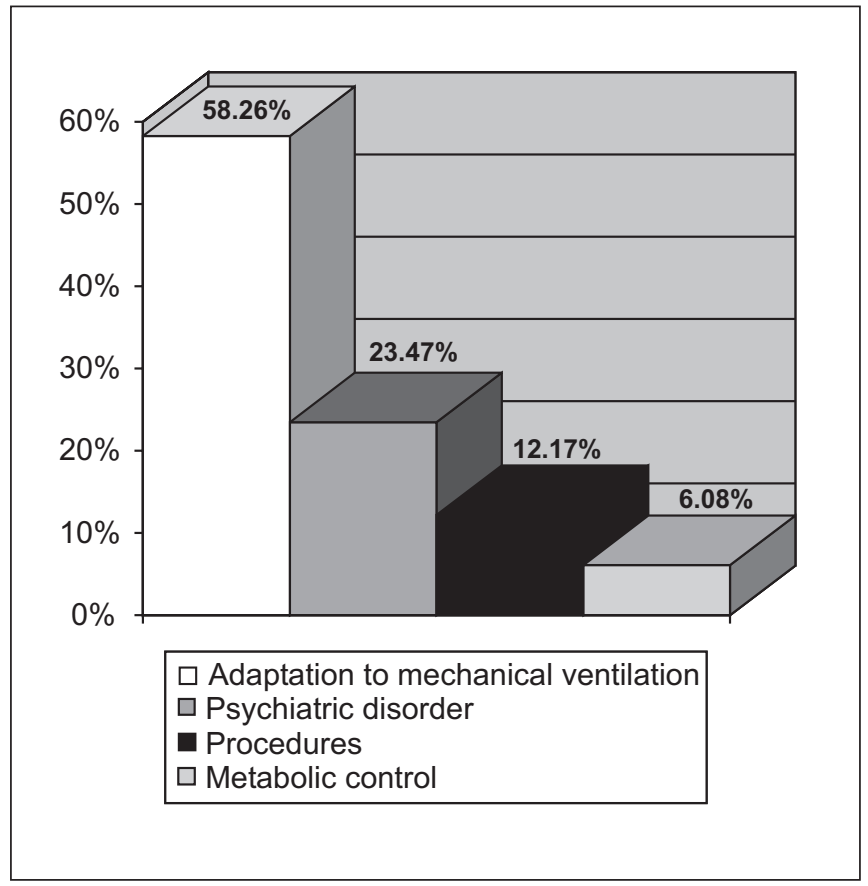

Figure 1 - Most Common Indications for the Use of Sedative Agents in Severely III Patients

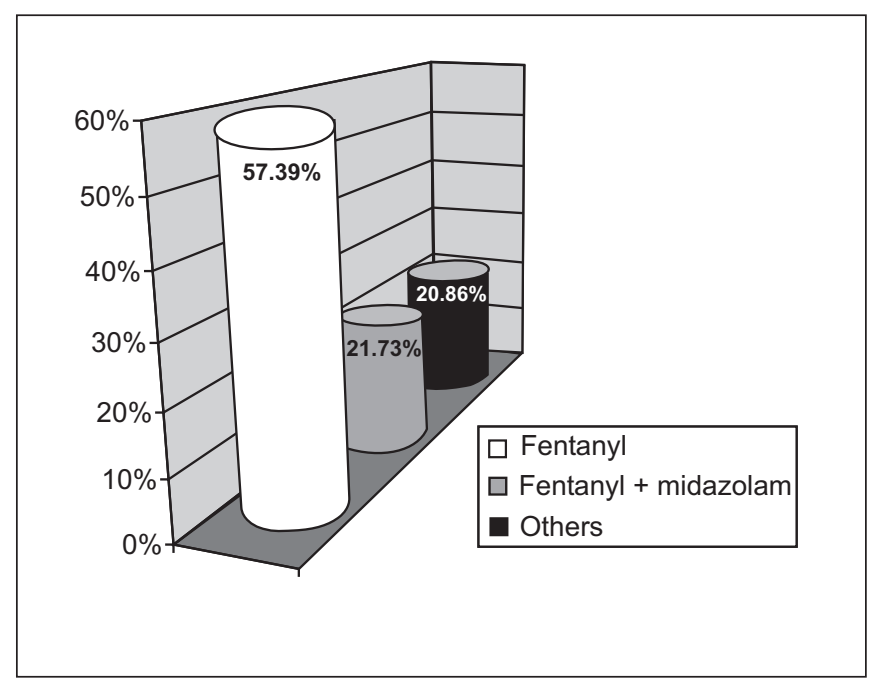

Figure 2 - Most Common Drugs Used for ICU Patients Sedation

Researchers have observed that, in several institutions, 40\% of patients under intensive care have received sedative drugs ${ }^{12}$. These results confirm other studies which have shown an intensive use of sedative drugs, administered to $30 \%$ to $50 \%$ of severely ill patients ${ }^{11,18}$.

In parallel to our study, it was observed that, if considering just patients admitted for more than 24 hours, sedatives were used in $37.4 \%$ of cases; this figure drops to $24.6 \%$ when considering all patients in the period, including the 182 excluded for remaining admitted for less than 24 hours, be it for death, for being organ donors or for lacking all requirements needed to calculate the severity index.

Revista Brasileira de Anestesiologia

Vol. 52, Nº 6, Novembro - Dezembro, 2002

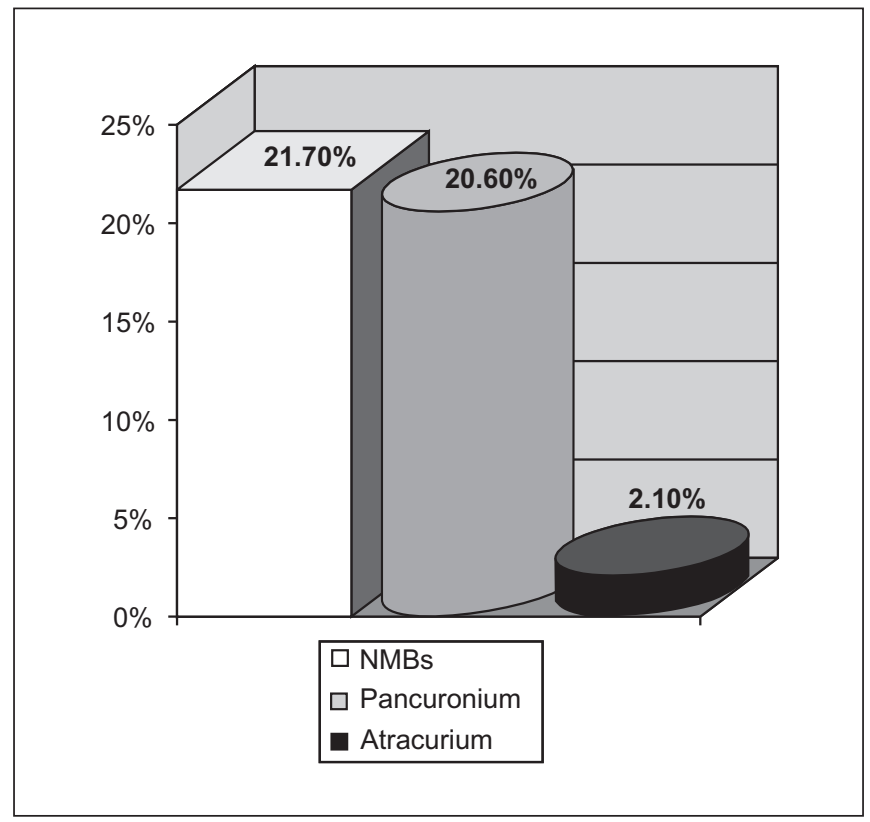

Figure 3 - Percentage of Mechanically Ventilated Patients Receiving Neuromuscular Blockers (NMB) and Most Widely Used NMBs

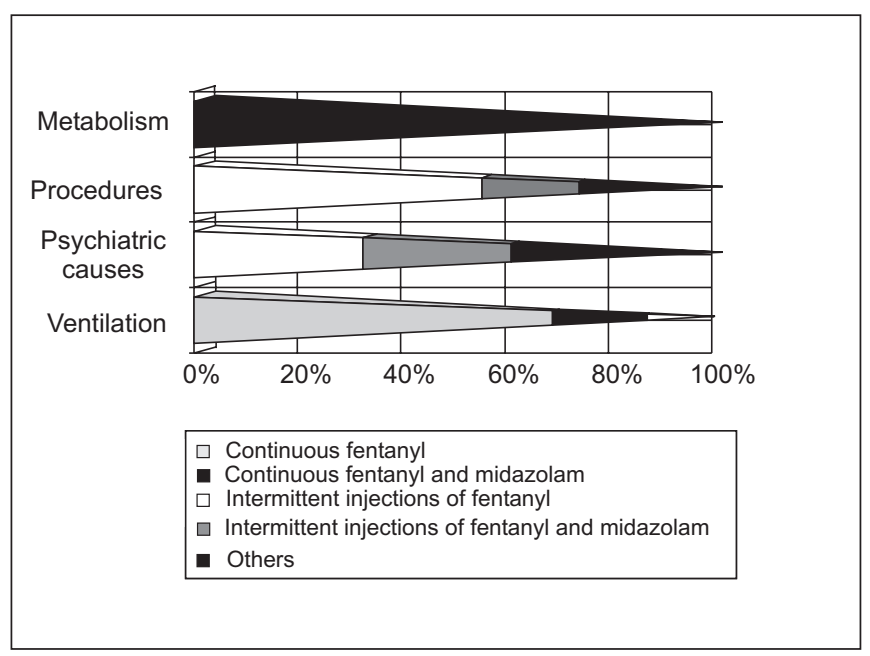

Figure 4 - Sedative Techniques and Agents Related to Most Common Indications

Intensive care requires patience and cooperation. Some patients have sensory changes as a direct consequence of an organic dysfunction ${ }^{19}$. In these cases, sedatives may be beneficial to decrease the psychological impact and help the treatment of somatic disorders ${ }^{1}$.

Most common psychiatric complications are delirium and agitation. Delirium includes sensoperception and sleep abnormalities, disorientation and psychomotor agitation ${ }^{20}$. A psychological support will decrease the incidence of such phenomena in $14 \%$ to $33 \%{ }^{10}$. Such disorders are seldom associated to true psychosis. The expression "ICU psychosis" is a simplistic and nonspecific description of behaviors resulting from the loss of contact with reality ${ }^{1}$. 
Fear and anxiety are relevant psychic stresses and are influenced by genetic factors and previous experiences (self or from friends). Anxiety may result in psychological disorganization expressed by delusion, panic, abandonment and even psychosis ${ }^{13}$. Some of these components were observed in our study in patients with agitation or delirium, and were generically grouped as psychiatric disorders. These causes were in general related to psychomotor agitation and corresponded to $25.77 \%$ of the indications for sedation.

A friendly team and a cozy environment (noise, light and temperature control) could prevent this devastating sequence. Family and friend visits highly reinforce the support provided by medical and paramedical staff ${ }^{10}$.

Respiratory problems are common in ICUs. Lung or non-lung diseases may lead to the need for prolonged or temporary ventilatory support. In such patients, tracheal tube, ventilator's monotone sound, in addition to fear and anxiety, prevent the synchronism between spontaneous and mechanical ventilation ${ }^{3}$. Anxiolitics and hypnotics may be useful to improve tolerance.

Tracheal tube tolerance is variable and nasotracheal catheters are better accepted. Tracheostomy does not call for sedation. Tracheal aspiration, however, has already been described as choking and reaching tolerability thresholds. Mechanical ventilation in early treatment may become a terrifying experience ${ }^{10}$. At this point, the association of opioids will be useful to decrease resistance to the ventilator and promote analgesia.

Adequate sedation and mechanical ventilation adjustment eliminate the need for neuromuscular blockers and excessive sedation in many adult patients. In spite of that, patient's adaptation to mechanical ventilation is a major indication for sedation, as it has been shown in this study where it was responsible for $57.73 \%$ of all circumstances in which sedatives were administered. Approximately $90 \%$ of patients submitted to mechanical ventilators receive such drugs, and this may reach $100 \%$ of cases.

Several procedures are performed under local anesthesia with no need for sedation. Extensive and aggressive interventions, however, need sedation or even general anesthe$\mathrm{sia}^{2}$. Tracheal intubation is an example of a situation requiring consciousness depression for a brief period of time ${ }^{13}$. This is why uncomfortable or painful procedures corresponded to $11.34 \%$ of all indications for sedation.

Since the loss of physiological sleep patterns has deep metabolic implications in hospitalized patients, the treatment of insomnia is a good reason for using sedatives, but it is not seen in more than $5.15 \%$ of cases.

The ideal sedation should meet patients' comfort needs without significant consciousness depression. So, tight limits make ICU sedation an exercise of medical art, where pharmacological interventions are just one factor, together with environmental control and team's sensitivity ${ }^{10,13}$.

Narcotics, associated or not to benzodiazepines, increase tracheal tube tolerance, minimize cough reflex and inhibit respiratory centers. So it is possible to adapt patients to the ventilator's automatic activity without however totally abolishing consciousness and cooperation.
Morphine is the most frequent agent for analgesia or sedation ( $37 \%$ alone and $60 \%$ associated to benzodiazepines) $)^{2,10,21}$. Fentanyl was the most common agent used in this study ( $58 \%$ of the techniques). It was administered alone in continuous infusion in $39.17 \%$ of cases and in isolated intermittent injections in $19.58 \%$ of cases. A recent Brazilian census, carried out by the Brazilian Association of Intensive Medicine (AMIB) ${ }^{22}$, has also shown the preference of most Brazilian specialists for fentanyl. However, according to the recommendations of the committee created by the American College and the American Society of Intensive Medicine (SCCM and ACCM $)^{23}$, morphine is the first choice, especially due to its low cost. The same committee has defined the use of fentanyl for situations of histamine release and hemodynamic instability. During the 1997 and 1999 AMIB meetings, the committee has recommended both morphine and fentanyl as the first option (available interventions or drugs recommended as from available scientific evidences and sufficient Brazilian clinical experience) ${ }^{24,25}$.

Benzodiazepines are the most prescribed drugs. Diazepam is still widely used for intensive care sedation 10,11,20. Midazolam is also widely used isolated ${ }^{26}$ or in association with narcotics ${ }^{27,28}$.

In our study, diazepam was primarily administered to treat tetanus (2 patients out of 307 ). The hypnotic drug of choice is, in general, midazolam, especially for its high hydrosolubility, short elimination half-life and relatively low cost. Propofol has several properties for ICU sedation, including extremely short half-life, even in prolonged infusions, and may be a better option than midazolam in several situations ${ }^{10,17,18}$. Its major limitation, however, is still the cost.

Haloperidol has been used in psychomotor agitation and is the drug of choice to treat delirium, according to SCCM and ACCCM consensus ${ }^{23}$; sodium thiobarbiturate ("barbiturate comma") is indicated to control intracranial hypertension and neurological suffering ${ }^{2,10,17}$; propofol in continuous infusion is indicated for sedation of patients under mechanical ventilation and has been seldom used in this study due to the few units acquired by the Hospital.

Diazepam, haloperidol, thiopental and propofol together, corresponded to $19.5 \%$ of all sedation techniques used in this study. Neuromuscular blockers complement sedation techniques in mechanically ventilated patients ${ }^{29}$. This combination (especially with pancuronium) has already been used in up to $91 \%$ of cases ${ }^{30}$. Other authors have observed the use of pancuronium in just $16 \%$ and $15 \%$ studied units ${ }^{11,22}$. In our study, pancuronium was administered to $20.6 \%$ of sedated patients, being only used in cases refractory to sedatives or with difficulties to maintain adequate ventilatory parameters. Atracurium is a useful NMB to a lesser extent ${ }^{30,31}$. This is stressed by its high cost and by the need for continuous use. It is of choice, however, in cases of renal failure, as it happened in all cases observed in this study.

Sedation is a frequent resource in ICUs, commonly indicated for mechanical ventilation adaptation and the treatment of psychomotor agitation. Fentanyl, alone or associated to midazolam, has been the most widely used agent. 


\section{REFERÊNCIAS - REFERENCES}

01. Crippen DW - The role of sedation in the ICU patient with pain and agitation. Crit Care Clin, 1990;6:369-372.

02. Dobb GJ, Murphy DF - Sedation and analgesia during intensive care. Clin Anaesth, 1985; 3:1055-1083.

03. Vinik HR \& Kissin I - Sedation in ITU. Intensive Care Med, 1991;17:S20-S23.

04. Gomes AMCG, Santos PAJ - Humanização em Medicina Intensiva, em: Amaral JLG - Clínicas Brasileiras de Medicina Intensiva: Sedação, Analgesia e Bloqueio Neuromuscular em UTI. São Paulo, Atheneu, 1997;13-46.

05. Tomlim PJ - Psychological problems in intensive care. Br Med J, 1977:2:441-443.

06. Benzer H, Mutz N, Pauser G - Psychological sequelae of intensive care. Int Anesthesiol Clin, 1983;21:169-180.

07. Brock-Utne JG, Cheetham RWS, Goodwin NM - Psychiatric problems in intensive care. Anaesthesia, 1976;31:380-384.

08. Helton MC, Gordon SH, Nunnery SL - The correlation between sleep deprivation and the intensive care unit syndrome. Heart \& Lung 1980;9:464-468.

09. Mindus $P$ - Anxiety, pain and sedation: some psychiatric aspects. Acta Anaesthesiol Scand, 1987;32:(Suppl.88):7-12.

10. Amaral JLG, Rodrigues Jr GR, Rocha RGA et al - Sedação, em: Amaral JLG - Clínicas Brasileiras de Medicina Intensiva: Sedação, Analgesia e Bloqueio Neuromuscular em UTI. São Paulo, Editora Atheneu, 1997;75-94.

11. Campos RA, Herraez FXV, Marcos RJ et al - Drug use in an intensive care unit and this relation to survival. Intensive Care Med, 1980;6:163-168.

12. Farina ML, Levatl A, Tognoni G - A multi-center study of ICU drug utilization. Intensive Care Med, 1981;7:125-131.

13. Wallace PGM, Bion JF, Ledingham I.Mc.A - The Changing Face of Sedative Practice. em: Ledingham I.Mc.A - Recent Advances in Critical Care Medicine. Edimburg, $1^{\text {st }}$ Ed, Churchill-Livingstone, 1988;3:70-93.

14. Berger MM, Marazzi A, Freeman J et al - Evaluation of the consistency of acute physiology and chronic health evaluation (APACHE II) scoring in a surgical Intensive Care Unit Crit Care Med, 1992;20:1681-1687.

15. Siegel S - Estatística no Parametrica. México, Ed. Trillas, 1975;346.

16. Bion JF, Chow B, Bowden MI - Aims and methods of assessment of sedation in Intensive Care J Drug Dev, 1991;4:(Suppl3):19-25

17. Aitkenhead AR - Analgesia and sedation in intensive care. $\mathrm{Br} \mathrm{J}$ Anaesth, 1989;63:196-206.

18. Buchanan N, Cane RD - Drug utilization in a general intensive care unit. Intensive Care Med, 1978;4:75-77.

19. Easton C, Mackenzie F - Sensory-perceptual alterations: delirium in the intensive care unit. Heart \& Lung, 1988;17:229-237.

20. Cassem EH, Lake CR, Boyer WF - Psychopharmacology in the ICU, em: Chernow B - The Pharmacological Approach to the Critically ill Patient. $2^{\text {nd }}$ Ed, Baltimore, Williams \& Wilkins, 1988, 491-510.

21. Bion JF, Ledingham I.Mc.A - Sedation in intensive care - a postal survey. Intensive Care Med, 1987;13:215-216.

22. Moritz R, Goldwasser R - Uso de sedativos em unidades de terapia intensivas brasileiras. Rev Bras Terap Intens, 1999;11:139-145.

23. Shapiro BA, Warren MD, Egol AB et al - Practice parameters for intravenous analgesia and sedation for adult patients in the intensive care unit: an executive summary. Crit Care Med, 1995;23: 1596-1600.

24. Amaral JLG, Réa Neto A, Conceição NA et al - I Consenso Brasileiro sobre Sedação, Analgesia e Bloqueio Neuromuscular em Terapia Intensiva, em: Amaral JLG - Clínicas Brasileiras de Medicina Intensiva, Sedação, Analgesia e Bloqueio Neuromuscular em UTI. $1^{\text {a }}$ Ed, São Paulo, Atheneu, 1997;241-255.
25. Amaral JLG, Issy AM, Conceição NA et al - II Consenso Brasileiro: Recomendações da Associação Brasileira de Medicina Intensiva sobre Sedação, Analgesia e Bloqueio Neuromuscular em Terapia Intensiva. São Paulo, AMIB, 1999.

26. Shafer A, Doze VA, White PF - Pharmacokinetic variability of midazolam infusions in critically III patients. Crit Care Med, 1990;18:1039-1041.

27. Pepperman ML - Double-blind study of the reversal of midazolam-induced sedation in the intensive care unit with flumazenil (Ro 15-1788): effect on weaning from ventilation. Anaesth Intens Care, 1990;18:38-44.

28. Geller E, Halpern P, Barzelal E et al - Midazolam and flumazenil for sedation in intensive care patients. Resuscitation, 1988;16: (Suppl):S31-S39.

29. Willats SM - Paralysis for ventilated patients? Yes or no? Intensive Care Med, 1985;11:2-4.

30. Peat SJ, Potter DR, Hunter JM - The prolonged use of atracurium in a patient with tetanus. Anaesthesia, 1988;43:962-963.

31. Pollard BJ, Harper NJM, Doran BRH - Use of continuous prolonged administration of atracurium in the ITU to a patient with myasthenia gravis. Br J Anaesth, 1989;62:95-97.

\section{RESUMEN}

Rodrigues Jr GR, Amaral JLG - Experiencia Clínica con el Uso de Sedativos en la Terapia Intensiva. Estudio Retrospectivo

Justificativa y Objetivos - Entre las indicaciones más frecuentes de sedación en pacientes internados en Unidades de Terapia Intensiva (UTI) están la institución y la manutención de ventilación artificial, la ansiedad y procedimientos desconfortables o dolorosos. El objetivo de este estudio retrospectivo fue verificar las indicaciones y las técnicas más comunes de sedación en pacientes graves internados en la Unidad de Terapia Intensiva Quirúrgica de la Escuela Paulista de Medicina (EPM/UNIFESP) durante un período de 11 meses.

Método - Después de haber sido excluidos los pacientes que permanecieron en la UTI menos de 24 horas o estaban sin exámenes indispensables para el cálculo del índice de gravedad (APACHE II), la muestra quedó reducida a 307 pacientes. Fueron analizadas las técnicas más utilizadas, las indicaciones de sedación y la asociación de bloqueadores neuromusculares.

Resultados - La sedación fue administrada en $37,4 \%$ de los pacientes. Entre las indicaciones de sedación están los disturbios de naturaleza psiquiátrica, como delirio, agitación, miedo y ansiedad. Éstas correspondieron a $25,77 \%$ de todas las indicaciones. La mayoría de los pacientes ventilados artificialmente también necesita de sedativos. Instalación y manutención de ventilación mecánica correspondieron a la mayoría de las indicaciones, alrededor de $57,73 \%$ de los pacientes sedados. Procedimientos como intubación traqueal y broncoscopia tuvieron $11,34 \%$ de las indicaciones y control del metabolismo (coma barbitúrico y tétano), 5,15\%. Las técnicas mas comúnmente utilizadas incluyeron opioides aislados o asociados a benzodiazepínicos. En este estudio, el fentanil fue utilizado en $58 \%$ de las técnicas, aisladamente, y en $21,64 \%$ asociado al midazolam. Haloperidol, diazepam, propofol y tiopental sumaron $19,5 \%$. Bloqueadores neuromusculares fueron utilizados en $22,7 \%$ de los casos en pacientes ventilados artificialmente.

Conclusiones - La sedación es un recurso terapéutico frecuente en la Terapia Intensiva, comúnmente utilizada para facilitar la ventilación artificial y tratar los problemas de naturaleza psiquiátrica. Fentanil, aisladamente o en asociación con midazolam, fue el agente más utilizado. 